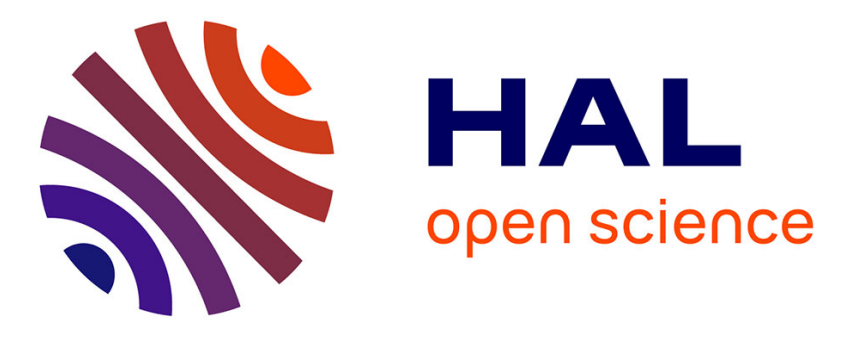

\title{
Sorption and Redox Speciation of Plutonium at the Illite Surface
}

Nidhu Lal Banik, Remi Marsac, Johannes Lützenkirchen, Alexandre Diascorn, Kerstin Bender, Christian M. Marquardt, Horst Geckeis

\section{- To cite this version:}

Nidhu Lal Banik, Remi Marsac, Johannes Lützenkirchen, Alexandre Diascorn, Kerstin Bender, et al.. Sorption and Redox Speciation of Plutonium at the Illite Surface. Environmental Science and Technology, 2016, 50 (4), pp.2092 - 2098. 10.1021/acs.est.5b05129 . hal-01904367

\section{HAL Id: hal-01904367 https://hal.science/hal-01904367}

Submitted on 24 Oct 2018

HAL is a multi-disciplinary open access archive for the deposit and dissemination of scientific research documents, whether they are published or not. The documents may come from teaching and research institutions in France or abroad, or from public or private research centers.
L'archive ouverte pluridisciplinaire HAL, est destinée au dépôt et à la diffusion de documents scientifiques de niveau recherche, publiés ou non, émanant des établissements d'enseignement et de recherche français ou étrangers, des laboratoires publics ou privés. 


\section{Sorption and Redox Speciation of Plutonium}

6 Karlsruhe, Germany

7 ABSTRACT. The geochemical behavior of Pu strongly depends on its redox speciation. In this

8 study we investigated $\mathrm{Pu}$ sorption onto Na-illite, a relevant component of potential host rocks for

9 high-level nuclear waste repositories, under anaerobic conditions. When contacting $\mathrm{Pu}(85 \%$

$10 \mathrm{Pu}(\mathrm{IV}), 11 \% \mathrm{Pu}(\mathrm{V})$ and $4 \% \mathrm{Pu}(\mathrm{III}) ; 8 \times 10^{-11}<[\mathrm{Pu}]_{\text {tot }} / \mathrm{M}<10^{-8}$ ) with illite in $0.1 \mathrm{M} \mathrm{NaCl}$ at $\mathrm{pH}$

11 between 3 and 10, Pu uptake was characterized by $\log \mathrm{R}_{\mathrm{d}}>4\left(\mathrm{R}_{\mathrm{d}}\right.$ : distribution coefficient in $\mathrm{L} \mathrm{kg}^{-}$

$\left.12^{1}\right)$. Small amounts of aqueous $\mathrm{Pu}(\mathrm{V})$ were detected in solution on contact with illite after one

13 week which is not expected to be stable at the measured redox potentials (Eh) in our experiments.

14 This observation suggests time dependent reduction of $\mathrm{Pu}(\mathrm{V})$ to $\mathrm{Pu}(\mathrm{IV})$. After one year, $\log \mathrm{R}_{\mathrm{d}}$

15 values had increased compared to those after one week due to the reduction of weakly adsorbing $16 \mathrm{Pu}(\mathrm{V})$. For $\mathrm{pH}<5, \mathrm{Pu}(\mathrm{IV})$ and $\mathrm{Pu}(\mathrm{III})$ coexisted in solution under our experimental conditions, 17 showing that $\mathrm{Pu}(\mathrm{IV})$ reduction to $\mathrm{Pu}(\mathrm{III})$ occurred in the illite suspension. Taking (i) surface 18 complexation constants determined for $\mathrm{Eu}(\mathrm{III})$-illite interaction (with redox insensitive $\mathrm{Eu}(\mathrm{III})$ as 19 a chemical analogue to $\mathrm{Pu}(\mathrm{III})$ ), (ii) the known constant for $\mathrm{Pu}(\mathrm{III}) / \mathrm{Pu}(\mathrm{IV})$ redox transition, and 20 (iii) measured $\mathrm{Eh}$ and $\mathrm{pH}$, overall $\mathrm{Pu}$ uptake was well predicted. 


\section{INTRODUCTION}

23 Due to its high radiotoxicity and the very long half-lives of some isotopes, plutonium $(\mathrm{Pu})$ is an

24 important element in the context of nuclear waste disposal. Under environmentally relevant 25 conditions, $\mathrm{Pu}$ can occur in the oxidation states $+\mathrm{III},+\mathrm{IV},+\mathrm{V}$ and $+\mathrm{VI}$. As the geochemical 26 behavior of $\mathrm{Pu}$, such as solubility and mobility, strongly depends on its redox state, ${ }^{1,2}$ thermodynamic speciation calculations need to account for Pu redox speciation.

Several studies have shown that actinide redox chemistry is affected by interaction with mineral surfaces. The evaluation of $\mathrm{Pu}$ sorption data is particularly challenging as frequently a mixture of $\mathrm{Pu}$ redox states is found in solid/liquid systems (i.e. at the surface and/or in solution). In the

31 presence of a mineral, rates for abiotic redox reactions range from a few hours to a few months and depend on the mineral type, $\mathrm{pH}, \mathrm{Pu}$ concentration and initial $\mathrm{Pu}$ redox state, which further complicates data interpretation. ${ }^{3-8}$ Generally, under ambient (air) atmosphere, when adding

$34 \mathrm{Pu}(\mathrm{IV}), \mathrm{Pu}(\mathrm{V})$ or $\mathrm{Pu}(\mathrm{VI})$ to a mineral suspension (hematite, goethite, magnetite, ${ }^{5-10}$ quartz, ${ }^{11}$ montmorillonite, ${ }^{3,4}$ kaolinite $\left.^{12}\right), \mathrm{Pu}(\mathrm{IV})$ is found at the mineral surface whereas very often $\mathrm{Pu}(\mathrm{V})$ prevails in solution. Similar observations were made for neptunium (Np) and illite under slightly

37 reducing conditions. ${ }^{13}$ However, the standard redox potential of the $\mathrm{Np}(\mathrm{V}) / \mathrm{Np}(\mathrm{IV})$ couple $38\left(E_{N p O_{2}^{+} / N p^{4+}}^{0}=0.604 \mathrm{~V}\right)$ is lower than that of the $\mathrm{Pu}(\mathrm{V}) / \mathrm{Pu}(\mathrm{IV})$ pair $\left(E_{\mathrm{PuO}}^{0} / \mathrm{Pu}^{4+}=1.031 \mathrm{~V}\right) .{ }^{14}$

$39 \mathrm{Pu}$ sorption to minerals under reducing conditions, where $\mathrm{Pu}(\mathrm{III})$ should prevail, has been probed 40 less frequently. Under inert $\left(\mathrm{N}_{2(\mathrm{~g})}\right.$ or $\left.\mathrm{Ar}_{(\mathrm{g})}\right)$ atmosphere, magnetite was shown to reduce $\mathrm{Pu}(\mathrm{V})$ to $41 \mathrm{Pu}(\mathrm{III})$ at $\mathrm{pH}=6$ and 8 , whereas $\mathrm{Pu}(\mathrm{III})$ was not observed under ambient atmosphere. ${ }^{7,15}$ In the presence of kaolinite and $\mathrm{NH}_{2} \mathrm{OH} \cdot \mathrm{HCl}$ added as a weaker reducing agent than magnetite, $\mathrm{Pu}(\mathrm{III})$

43 was oxidized to $\mathrm{Pu}(\mathrm{IV})$ at $\mathrm{pH}>6 .{ }^{16}$ Banik et al. ${ }^{13}$ noticed the presence of $\mathrm{Pu}(\mathrm{III})$ at $\mathrm{pH}=1$ in the 44 solution when in contact with kaolinite under ambient atmosphere, which is explained by the 
higher stability of $\mathrm{Pu}(\mathrm{III})$ at low $\mathrm{pH}$. All these studies suggest that $\mathrm{Pu}$ redox speciation is strongly

46 affected by the redox conditions in the investigated system and the presence of mineral surfaces. In recent studies, it was shown that the overall uptake of redox sensitive actinides can be quantitatively predicted by taking into account the uptake of the individual redox states and the measured redox potentials, i.e. the negative logarithm of (apparent) electron activity, pe. In the case of $\mathrm{Np}$, the high stability of $\mathrm{Np}(\mathrm{IV})$ surface complexes significantly extended the predominance field of $\mathrm{Np}(\mathrm{IV})$ at the illite surface as compared to that valid for the pure aqueous solution. This finding explains the prevalence of $\mathrm{Np}(\mathrm{V})$ in solution and of $\mathrm{Np}(\mathrm{IV})$ at the surface.

53 Overall $\mathrm{R}_{\mathrm{d}}$ values obtained for the sorption of $\mathrm{Np}$ thus lie between that of penta- and tetravalent 54 actinides. $^{13}$ The same modeling approach was applied to simulate $\mathrm{Pu}$ sorption and redox 55 speciation at the kaolinite surface. ${ }^{17}$ Lanthanides and actinides are known to exhibit similar 56 chemical behavior for a given redox state. ${ }^{1,2,18}$ Because separate uptake data for the four distinct $57 \mathrm{Pu}$ redox states are not available (and will be difficult to obtain experimentally), sorption data for 58 europium(III) or americium(III) $\left(\mathrm{Eu}^{3+} / \mathrm{Am}^{3+}\right)$, thorium(IV) $\left(\mathrm{Th}^{4+}\right)$, neptunium(V) $\left(\mathrm{NpO}_{2}^{+}\right)$and 59 uranium(VI) $\left(\mathrm{UO}_{2}{ }^{2+}\right)$ were used to estimate sorption data of the respective $\mathrm{Pu}$ redox states. As 60 both $\mathrm{Pu}(\mathrm{IV})$ and $\mathrm{Pu}(\mathrm{III})$ show strong sorption to mineral surfaces over a wide range of $\mathrm{pH}$ 61 conditions, $\mathrm{Pu}(\mathrm{IV})$ and $\mathrm{Pu}(\mathrm{III})$ predominance fields are expected to be less affected by the 62 presence of mineral surfaces than in the case of $\mathrm{Np},{ }^{13,17}$ where the sorption behavior of the redox 63 species $+\mathrm{V}$ and $+\mathrm{IV}$ are clearly different.

$64 \mathrm{Pu}$ sorption onto purified illite ${ }^{13}$ in $0.1 \mathrm{M} \mathrm{NaCl}$ is experimentally investigated in the present study 65 under anaerobic conditions in order to verify the reliability and applicability of those previously reported modeling approaches. Pu sorption to illite is interpreted involving known data on redox

67 and adsorption equilibria within the 2 site protolysis non-electrostatic surface complexation and 68 cation exchange (2 SPNE SC/CE) model ${ }^{19-21}$ to quantify Pu surface speciation. 


\section{MATERIALS AND METHODS}

All chemicals (pro analytical quality or better) were obtained from Merck (Darmstadt, Germany) or Riedel de Haen (Seelze, Germany). Solutions were prepared with de-ionized "MilliQ" water (specific resistivity, $18.2 \mathrm{M} \Omega \mathrm{cm}^{-1}$ ). The purified Na-illite was provided within the EC project CP CatClay (www.catclay.org). The source material derives from lacustrine continental sediments deposited at the Upper Eocene ( -35 Ma) in the basin of Le Puy en Velay (Massif Central, France). The purification procedures and the characterization of the purified illite $(<63 \mu \mathrm{m})$ were previously given in detail ${ }^{13}$ and will not be repeated here. Note that in the last step of the purification, the clay suspension was freeze dried, to exclude bacterial activity.

8

Plutonium and Europium stock solution. A ${ }^{238} \mathrm{Pu}$ stock solution was prepared from a solution of plutonium dissolved in concentrated nitric acid, which was fumed three times by 0.1 $\mathrm{M} \mathrm{HClO}_{4}$, in order to remove nitrate and organic traces. The concentration of the $\mathrm{Pu}$ stock solution was $3.9 \times 10^{-5} \mathrm{M}$ in $0.1 \mathrm{M} \mathrm{HClO}_{4}$. A more dilute solution $\left([\mathrm{Pu}]=1.9 \times 10^{-6} \mathrm{M}\right)$ in $0.1 \mathrm{M}$ $\mathrm{HClO}_{4}$ was prepared from that stock solution - however, the solution was left under argon atmosphere for several months before dilution - to perform experiments at low $\mathrm{Pu}(\mathrm{IV})$ concentration. The concentrations of ${ }^{238} \mathrm{Pu}$ in solution were determined by liquid scintillation counting (LSC) using the scintillation cocktail Ultima Gold XR with a liquid scintillation analyzer (Tri-Carb $3110 \mathrm{TR})$. In addition, the stock solution of ${ }^{238} \mathrm{Pu}$ were checked by ICP-MS measurements and the results were in excellent agreement with LSC measurements.

$9 \mathrm{Eu}(\mathrm{III})$ was investigated as a chemical analogue of $\mathrm{Pu}(\mathrm{III})$. A radiotracer solution was purchased 0 from Amersham International (total $\mathrm{Eu}$ concentration: $6.0 \times 10^{-4} \mathrm{M}$ ) with isotopic composition: ${ }^{151} \mathrm{Eu}(83 \%),{ }^{152} \mathrm{Eu}\left(13 \%, \mathrm{t}_{1 / 2}=13.33 \mathrm{a}\right),{ }^{153} \mathrm{Eu}(4 \%) .{ }^{152} \mathrm{Eu}$ is a $\beta$-, $\gamma$-emitter and can be 
conveniently analyzed by $\gamma$-counting. In the present study, precise determination of dissolved ${ }^{152}$ Eu concentration, was performed using a Perkin Elmer Wallac gamma counter (Wizard 1480).

Plutonium redox state analysis by liquid-extraction methods. The Pu redox state distribution in the diluted ${ }^{238} \mathrm{Pu}$ stock solution $\left(1.9 \times 10^{-6} \mathrm{M}\right.$; in $\left.0.1 \mathrm{M} \mathrm{HClO}_{4}\right)$ and in the supernatant of $\mathrm{Pu}$-illite samples prepared for $[\mathrm{Pu}]_{\text {tot }}=10^{-8} \mathrm{M}$ was determined by liquid-liquid extraction. ${ }^{22,23}$ Two different complexing agents, 0.025 M PMBP in toluene and 0.5 M HDEHP in xylene, were used (PMBP: 4-benzoyl-3-methyl-1-phenyl-pyrozolin-5-one; HDEHP: phosphoric acid bis-(2-ethyl-hexyl) ester). ${ }^{22,23}$ The aqueous Pu-sample solution mixed with the organic extractant was stirred for 10 minutes and then centrifuged for 10 minutes at 4000 rounds per minute (rpm). After separation of the aqueous and the organic phases, activities were measured in each phase by LSC. Four different extractions were made separately. With PMBP at $\mathrm{pH} 0$ (extraction 1), $\mathrm{Pu}(\mathrm{IV})$ is extracted into the organic phase, while $\mathrm{Pu}(\mathrm{III}), \mathrm{Pu}(\mathrm{V}), \mathrm{Pu}(\mathrm{VI})$ and polymers remain in the aqueous phase. With $\mathrm{PMBP}$ at $\mathrm{pH} 0$ and $0.02 \mathrm{M} \mathrm{Cr}_{2} \mathrm{O}_{7}{ }^{2-}$ (extraction 2), $\mathrm{Pu}(\mathrm{III})$ and $\mathrm{Pu}(\mathrm{IV})$ are extracted into the organic phase, while $\mathrm{Pu}(\mathrm{V}), \mathrm{Pu}(\mathrm{VI})$ and polymers remain in the aqueous phase. With $\mathrm{HDEHP}$ at $\mathrm{pH} 0$ (extraction 3), $\mathrm{Pu}(\mathrm{IV})$ and $\mathrm{Pu}(\mathrm{VI})$ are extracted into the organic phase, while $\mathrm{Pu}(\mathrm{III}), \mathrm{Pu}(\mathrm{V})$ and polymers remain in the aqueous phase. With HDEHP at pH 0 and $0.02 \mathrm{M} \mathrm{Cr}_{2} \mathrm{O}_{7}{ }^{2-}$ (extraction 4), $\mathrm{Pu}(\mathrm{III}), \mathrm{Pu}(\mathrm{IV}), \mathrm{Pu}(\mathrm{V})$ and $\mathrm{Pu}(\mathrm{VI})$ are extracted into the organic phase while polymers remain in the aqueous phase. All steps for the separation of the different oxidation states of plutonium and the calculation leading to the aqueous redox speciation of $\mathrm{Pu}$ are outlined in the supporting information (Figure S1). The uncertainty of the method is conservatively estimated to be $\pm 10 \%$, and includes the pipetting error, phase separation of mixture, quenching factor of the analyte solution (color) for the LSC 
115 measurements and the variability observed for different extraction experiments. The diluted ${ }^{238} \mathrm{Pu}$ 116 stock solution contained $85 \% \mathrm{Pu}(\mathrm{IV}), 11 \% \mathrm{Pu}(\mathrm{V})$ and $4 \% \mathrm{Pu}(\mathrm{III})$. Seemingly, the $\mathrm{Pu}(\mathrm{VI})$ 117 expected from the preparation step is not stable at low concentrations under the present 118 experimental conditions, which was also observed by Neck et al. ${ }^{24}$

120 Determination of $\mathbf{p H}$ and Eh. The $\mathrm{pH}$ in the clay suspensions was measured by an Orion $121525 \mathrm{~A}(\mathrm{pH}$ meter) and a Ross electrode calibrated with 4 standard buffers (pH 3, 5, 7 and 9; 122 Merck). The error in $\mathrm{pH}$ measurements is \pm 0.05 . The redox potentials in the clay suspensions 123 were measured using an Orion 525A ( $\mathrm{E}_{\mathrm{h}}$ meter) and a Pt electrode combined with the $\mathrm{Ag} / \mathrm{AgCl}$ 124 reference system (Metrohm). Raw data were converted into Eh vs. standard hydrogen electrode 125 (SHE) by correcting for the potential of the reference electrode. Eh was converted to the apparent 126 electron activity, pe $=-\log \mathrm{a}_{\mathrm{e}-}=16.9 \times \mathrm{Eh}(\mathrm{V})$ at $25^{\circ} \mathrm{C}$. A commercial redox-buffer $(220 \mathrm{mV}$, 127 Schott instruments) was used for calibration. After having stirred the suspension, a time span of 12815 min was allowed for all Eh measurements. Uncertainties in Eh measurements are $\pm 50 \mathrm{mV} .^{15,24}$

130 Batch sorption experiments. All sorption studies were performed as batch type 131 experiments. The effect of $\mathrm{pH}$ was investigated for an initial $\mathrm{Pu}$ concentration $\left([\mathrm{Pu}]_{\mathrm{tot}}\right)$ of $8 \times 10^{-11}$ $132 \mathrm{M}$. In addition, the effect of $[\mathrm{Pu}]_{\text {tot }}$ was investigated for $8 \times 10^{-11}<[\mathrm{Pu}]_{\text {tot }}<10^{-8} \mathrm{M}$, at $\mathrm{pH} \approx 4,7$ 133 and 10. Batch experiments were carried out in $40 \mathrm{~mL}$ polypropylene centrifuge tubes at room 134 temperature in an argon glove box $\left(<1 \mathrm{ppm} \mathrm{O}_{2}\right.$, absence of $\left.\mathrm{CO}_{2}\right)$. The suspension volume was 25 $135 \mathrm{~mL}$. At a solid to liquid ratio of $2 \mathrm{~g} \mathrm{~L}^{-1}$, the suspensions were preconditioned in $0.1 \mathrm{M} \mathrm{NaCl}$ 136 under continuous shaking for 4-5 days to achieve a given target $\mathrm{pH}$ value by adding $0.1 \mathrm{M} \mathrm{HCl}$ or $1370.1 \mathrm{M} \mathrm{NaOH}$. After adding $\mathrm{Pu}$ to the illite suspension, $\mathrm{pH}$ was adjusted again to the required $\mathrm{pH}$ 
138 of the sample. Neither $\mathrm{pH}$ nor Eh buffers were used. The samples were closed and shaken end-

139 over-end. After one week, $\mathrm{pH}$ and Eh were measured in the suspension and an aliquot of each 140 sample was transferred to special centrifuge tubes (Beckmann, Recorder No.: 356562) and 141 centrifuged (Beckmann Coulter XL-90 K) at 90,000 rpm ( 700,000 g max) for one hour. The 142 supernatant was analyzed for dissolved Pu by LSC. Samples were kept in the glovebox without 143 any $\mathrm{pH}$ adjustment and the procedure was repeated after one year of contact time. Results from 144 the batch experiments are expressed throughout as distribution coefficients $\left(\mathrm{R}_{\mathrm{d}}\right.$ in $\left.\mathrm{L} \mathrm{kg}^{-1}\right)$, 145 calculated by the following equation:

149 where $[\mathrm{Pu}]_{\mathrm{aq}}$ and $[\mathrm{Pu}]_{\mathrm{tot}}(\mathrm{M})$ are the dissolved (final) equilibrium and total (initial) concentrations 150 of $\mathrm{Pu}$, respectively. The term $\mathrm{V} / \mathrm{m}$ corresponds to the aqueous solution volume to illite mass ratio 151 ( $\left.\mathrm{L} \mathrm{kg}^{-1}\right)$. According to our experimental results (see below), an uncertainty of \pm 0.2 (standard 152 deviation) is assigned to $\log \mathrm{R}_{\mathrm{d}}$, although it could be larger according to comparable studies 153 where more than $99 \%$ uptake is obtained. ${ }^{20,21}$ Under such conditions, larger uncertainties are 154 induced by analytical constraints.

155 Batch Eu sorption experiments were performed for $[\mathrm{Eu}]_{\mathrm{tot}}=3 \times 10^{-9} \mathrm{M}$ applying the same protocol 156 as for $\mathrm{Pu}$, except that Eh was not recorded because $\mathrm{Eu}$ is not redox sensitive under our 157 experimental conditions. After one week contact time and subsequent ultracentrifugation, the 158 supernatant was analyzed for dissolved Eu by $\gamma$-spectrometry. The latter procedure was repeated 159 after 4 months to estimate potential aging effects on Eu sorption to illite. No aging effect is 160 observed for Eu(III) under our experimental conditions (see Fig. S2). 
162 Thermodynamic modeling. pe-pH diagrams for $\mathrm{Pu}$ were constructed using PhreePlot, ${ }^{25}$

163 which contains an embedded version of the geochemical speciation program PHREEQC. ${ }^{26}$

164 Thermodynamic constants for $\mathrm{Pu}$ and $\mathrm{Eu}$ aqueous speciation were taken from the NEA 165 thermodynamic database. ${ }^{14}$ The specific ion interaction theory $(\text { SIT })^{27}$ was used for the 166 calculation of the activity coefficients of aqueous species. In case of gaps in the Pu database, data 167 for analogues were chosen (i.e. $\mathrm{Eu}(\mathrm{III}), \mathrm{Np}(\mathrm{IV}), \mathrm{Np}(\mathrm{V})$ and $\mathrm{U}(\mathrm{VI})$ for the respective $\mathrm{Pu}$ redox 168 states). Auxiliary reactions and constants (from the SIT database) are provided with PHREEQC 169 (sit.dat file). The 2 SPNE SC/CE model was used to simulate Pu and Eu sorption to illite, where 170 the cation exchange capacity (CEC) and the strong site density of the illite surface are considered 171 equal to $0.225 \mathrm{eq} \mathrm{kg}^{-1}$ and $2 \times 10^{-3} \mathrm{~mol} \mathrm{~kg}^{-1}$, respectively. ${ }^{19-21}$ Only the strong sites within the 2 172 SPNE SC/CE model are considered in the adsorption calculations. The weak sites play a 173 negligible role in our experiments, since a maximum Pu loading of only $5 \times 10^{-6} \mathrm{~mol} \mathrm{~kg}^{-1}$ (i.e. for $\left.174[\mathrm{Pu}]_{\mathrm{tot}}=10^{-8} \mathrm{M}\right)$ is investigated. A complete summary of the thermodynamic database, SIT 175 coefficients and parameters for the 2SPNE SC/CE model is given in the supporting information 176 (Table S1, S2 and S3).

178 RESULTS AND DISCUSSION

179 Pu sorption to illite in 0.1 M NaCl. pH-pe data recorded after 1 week and 1 year 180 equilibration time in the $\mathrm{Pu}$-illite suspension in $0.1 \mathrm{M} \mathrm{NaCl}$ solution are plotted in Figure 1 181 together with the calculated predominance $\mathrm{pH}$-pe diagram for dissolved $\mathrm{Pu}$. The solid lines 182 correspond to equal amounts of two Pu redox states. Large symbols indicate the samples where 183 the supernatant was additionally analyzed by liquid extraction $\left([\mathrm{Pu}]_{\text {tot }}=10^{-8} \mathrm{M}\right.$; see Table S4 and 
184 S5 for more information regarding these samples). Data are compared to those reported for the 185 Np-illite system at similar metal ion concentration $\left(3 \times 10^{-8} \mathrm{M}\right)$ and after contact times between 7 and 63 days $^{13}$ and agree well within experimental uncertainties. Between 1 week and 1 year, $\mathrm{pH}$ may slightly evolve due to further buffering of illite, since no pH-buffer was used. An increase in pe values is also observed for the batch series prepared to study the effect of $\mathrm{pH}\left([\mathrm{Pu}]_{\mathrm{tot}}=8 \times 10^{-11}\right.$ $\mathrm{M})$, which is potentially due to the presence of undetectable traces of $\mathrm{O}_{2(\mathrm{~g})}$ (i.e. $\left.<1 \mathrm{ppm}\right)$ during sample handling or storage over the 1 year period. This has, however, no impact on our conclusions, which are based on the finally established pe and $\mathrm{pH}$ values. Batch series conducted 192 for $\mathrm{pH} \approx 4,7$ and $10\left(8 \times 10^{-11}<[\mathrm{Pu}]_{\mathrm{tot}}<10^{-8} \mathrm{M}\right)$ exhibit quite stable pe values with time, which 193 suggests no significant $\mathrm{O}_{2(\mathrm{~g})}$ contamination or microbial activity over the 1 year period.

194 Significant amounts of $\mathrm{Pu}(\mathrm{III})$ are expected in the aqueous phase below $\mathrm{pH} \approx 5$ whereas $\mathrm{Pu}(\mathrm{IV})$ 195 should prevail above $\mathrm{pH} \approx 6$ according to the calculations and taking pe data uncertainties into 196 account. However, in sorption experiments $\left([\mathrm{Pu}]_{\mathrm{tot}}=10^{-8} \mathrm{M}\right)$ performed over a period of 1 week, 197 we found at $\mathrm{pH}=4.3$ about $90 \%$ of the $\mathrm{Pu}$ in the supernatant aqueous phase being pentavalent 198 (Table S5). In analogy to the observed behavior of $\mathrm{Np}(\mathrm{V})$, the $\mathrm{Pu}(\mathrm{V})$ sorption to illite at $\mathrm{pH}=4.3$ 199 is considered negligible and remains in solution. $\mathrm{Pu}(\mathrm{IV})$, like other tetravalent actinide ions, is 200 expected to be almost completely sorbed (see e.g. the literature $\mathrm{Np}(\mathrm{V})$ - and $\mathrm{Th}(\mathrm{IV})$-illite sorption 201 data in Fig. S2 and Fig. S3, respectively). ${ }^{21,28}$ In our sample, only $7 \%$ of the total Pu remain in 202 solution. Therefore, $\mathrm{Pu}(\mathrm{V})$ represents $\sim 6 \%$ of the total $\mathrm{Pu}$ amount in the system, which 203 corresponds to about half of $\mathrm{Pu}(\mathrm{V})$ initially present in the ${ }^{238} \mathrm{Pu}$ stock solution $(11 \%$ of $\mathrm{Pu}(\mathrm{V}))$. At $204 \mathrm{pH}=6.9$, only $3 \%$ of $\mathrm{Pu}$ remain in solution after ultracentrifugation with $20 \% \mathrm{Pu}(\mathrm{V})$, while at $\mathrm{pH}$ $205=10$ the redox state of $\mathrm{Pu}$ in solution is entirely $+\mathrm{IV}$ after 1 week. We attribute this finding to a 206 time dependent $\mathrm{Pu}(\mathrm{V})$ reduction in our system which apparently accelerates with increasing $\mathrm{pH}$. 207 A similar time dependent reduction of $\mathrm{Pu}(\mathrm{V})$ to $\mathrm{Pu}(\mathrm{IV})$ was observed in presence of hematite and 
208 goethite, ${ }^{6,8,9}$ montmorillonite ${ }^{3,4}$ and other minerals. ${ }^{3,11}$ Reanalysis after 1 year revealed stronger $209 \mathrm{Pu}$ sorption and $\mathrm{Pu}$ redox states $\left([\mathrm{Pu}]_{\text {tot }}=10^{-8} \mathrm{M}\right)$ in the aqueous phase are now in better 210 agreement with thermodynamic considerations. At $\mathrm{pH}=4.3,22 \pm 10 \% \mathrm{Pu}(\mathrm{III}), 85 \pm 10 \% \mathrm{Pu}(\mathrm{IV})$

211 and no $\mathrm{Pu}(\mathrm{V})$ is detected. According to the measured pe data range $(6.2 \pm 0.9)$, between $88 \%$ and $212100 \%$ of $\mathrm{Pu}(\mathrm{III})$ are predicted to exist in solution and $0-12 \% \mathrm{Pu}(\mathrm{IV})$ which qualitatively agrees 213 with the experimental results. At $\mathrm{pH}=6.9$ and $9.3, \mathrm{Pu}(\mathrm{IV})$ clearly dominates and no significant 214 amounts of $\mathrm{Pu}(\mathrm{V})$ or $\mathrm{Pu}(\mathrm{III})$ could be found, as calculated using the measured pe values. We have 215 to emphasize that the observed time dependent redox reaction relates to only the initial $\mathrm{Pu}(\mathrm{V})$, i.e. 216 a small fraction of the total $\mathrm{Pu}$. The major $\mathrm{Pu}$ fraction is sorbed, either as $\mathrm{Pu}(\mathrm{III})$ or $\mathrm{Pu}(\mathrm{IV})$. 217 However, those small variations have a significant impact on $R_{d}$ values, as will be discussed 218 below. It is also understood that the time for attaining overall equilibrium might be shorter than 1 219 year. Such a long waiting period has been chosen in order to make sure that equilibrium has 220 established similar to the procedure proposed in a previous Pu-montmorillonite sorption study. ${ }^{3}$

221 Figure 2a shows $\mathrm{Pu}$ sorption to illite $\left(\mathrm{R}_{\mathrm{d}}\right.$ : distribution coefficient in $\left.\mathrm{L} \mathrm{kg}^{-1}\right)$ as a function of $\mathrm{pH}$ 222 after 1 week and 1 year contact time for $8 \times 10^{-11}<[\mathrm{Pu}]_{\text {tot }}<10^{-8} \mathrm{M}$. While $\mathrm{Pu}$ uptake by illite is 223 always high, $\mathrm{R}_{\mathrm{d}}$ values after 1 week are lower for $\mathrm{pH}<7$ than after 1 year (except for some data 224 at $\mathrm{pH}=4.3$, which will be discussed later). This is consistent with the disappearance of $\mathrm{Pu}(\mathrm{V})$, 225 which sorbs weakly compared to $\mathrm{Pu}(\mathrm{IV})$ and $\mathrm{Pu}(\mathrm{III})$. Earlier studies dealing with $\mathrm{Np}(\mathrm{V})$-illite 226 interaction $^{13}$ revealed faster redox reactions and equilibrium was assumed to be established after 2271 week. However, under those $\mathrm{pH} / \mathrm{pe}$ conditions, Np prevails in pentavalent state in solution 228 according to measurements and geochemical calculations which makes $\mathrm{Np}$ different from $\mathrm{Pu}$. 229 Consequently, $\mathrm{R}_{\mathrm{d}}$ values for $\mathrm{Np}$ are smaller than those observed for $\mathrm{Pu}$, so that slight variations in 230 redox have less impact on $\mathrm{R}_{\mathrm{d}}$ values for $\mathrm{Np}$ as compared to those for $\mathrm{Pu}$. Slow redox kinetics for 231 Np can thus not be excluded but the error related to kinetics might have been negligible 
232 compared to, for instance, experimental uncertainty on pe. Other mechanisms such as 233 incorporation reactions or sorption by secondary phases might also explain slow reaction rates.

234 Such reactions have been reported for mineral phases with high surface dynamics such as calcite, 235 apatite and brucite which can be estimated from known mineral dissolution rates (see e.g. ${ }^{2,29}$ ).

236 By contrast, dissolution rates of clays (e.g., for smectite) $)^{30}$ are slow and actinide incorporation in 237 clays has rarely been observed in laboratory studies, ${ }^{2}$ except at high $\mathrm{pH}$ (i.e. $\left.\mathrm{pH}>12\right)^{31}$ or in 238 coprecipitation studies. ${ }^{32}$ Moreover, sorption of redox inactive radionuclides such as Eu(III) and $239 \mathrm{Am}(\mathrm{III})$ to clays is relatively fast and proceeds within less than 1 week. ${ }^{20,21}$ For instance, as 240 shown in Figure S2, Eu(III) sorption to illite does not evolve significantly between 1 week and 4 241 months equilibration time. Although incorporation processes of $\mathrm{Pu}(\mathrm{III} / \mathrm{IV} / \mathrm{V})$ in illite cannot be 242 entirely excluded for the 1 year old samples, they very likely play a minor role with respect to the 243 increase in $\mathrm{R}_{\mathrm{d}}$ with time compared to $\mathrm{Pu}(\mathrm{V})$ reduction to $\mathrm{Pu}(\mathrm{IV})$.

244 Given the general agreement of results of thermodynamic calculations with experimentally 245 determined $\mathrm{Pu}$ redox states in solutions in contact with illite for 1 year, we assume establishment 246 of an overall equilibrium. Pu uptake by illite after 1 year contact time (Figure 2a) is characterized 247 by a constant $\log \mathrm{R}_{\mathrm{d}}=5.2 \pm 0.2(1 \sigma)$ for $\mathrm{pH}>5$. Sorption of tetravalent elements onto minerals is 248 reported to be widely insensitive to $\mathrm{pH}$ as for $\mathrm{Sn}(\mathrm{IV})$ and $\mathrm{Th}(\mathrm{IV})$ sorption to illite shown in 249 Figure $\mathrm{S} 3 .^{20,21} \mathrm{Pu}$ sorption data $\left(\log \mathrm{R}_{\mathrm{d}}\right)$ for $\mathrm{pH}>5$ are plotted in figure $2 \mathrm{~b}$ against the logarithm 250 of the final aqueous $\mathrm{Pu}$ concentration $\left(\log [\mathrm{Pu}]_{\mathrm{aq}}\right) .[\mathrm{Pu}]_{\mathrm{aq}}$ in presence of illite is close to or below 251 the solubility limit of $\mathrm{Pu}(\mathrm{IV})$ in equilibrium with $\mathrm{PuO}_{2 \text { (am,hydr) }}$ (i.e. $\log [\mathrm{Pu}]_{\mathrm{aq}} \approx-10.4$, for $\mathrm{pH}>$ 252 6). ${ }^{24}$ Precipitation of $\mathrm{PuO}_{2(\mathrm{am}, \mathrm{hydr})}$ can thus be excluded. Figure $2 \mathrm{~b}$ shows that $\log \mathrm{R}_{\mathrm{d}}$ is 253 independent of the total $\mathrm{Pu}$ concentration and does not vary with $\log [\mathrm{Pu}]_{\mathrm{aq}}$ for $\mathrm{pH}>5$. This is in 254 line with previous studies of Th(IV) sorption onto illite-containing argillaceous rocks (where 255 illite was shown to be the major adsorbant), where an ideal Th(IV) sorption was observed for a 
256 similar range of Th(IV) to clay concentration ratios for $7<\mathrm{pH}<8 .{ }^{33,34}$ Lower sorption of $\mathrm{Pu}$ at $257 \mathrm{pH}=3$ (figure 2a) can be attributed to the prevalence of less sorbing $\mathrm{Pu}(\mathrm{III})$, which is more stable 258 at low $\mathrm{pH}$ (Fig. 1). Different sorption behavior of tri- and tetravalent metal ions at such low $\mathrm{pH}$ is 259 well known for e.g. $\mathrm{Eu}(\mathrm{III})$ and $\mathrm{Th}(\mathrm{IV}) .{ }^{19-21}$ Scattering $\mathrm{R}_{\mathrm{d}}$ data obtained for $\mathrm{pH}=4.3$ might 260 suggest a concentration-dependent uptake of $\mathrm{Pu}$ (figure 2b). However, this is very unlikely 261 because investigated surface coverages (between $4 \times 10^{-8}$ and $5 \times 10^{-6} \mathrm{~mol}$ of Pu per kg of illite) are 262 below the saturation of any high affinity sites for illite, where an ideal sorption behavior has been 263 evidenced for many metal ions (see e.g. Figure 2 in reference 13, and references therein). Instead, $264 \log \mathrm{R}_{\mathrm{d}}$ variations at $\mathrm{pH}=4.3$ might be explained by the observed uncertainties of measured pe 265 data close to the $\mathrm{Pu}(\mathrm{IV}) / \mathrm{Pu}(\mathrm{III})$ borderline in Fig. 1 and possible slight heterogeneities in illite 266 samples (e.g. with regard to Fe(II)-content). Log $R_{d}$ seems to increase with pe (Fig. 2c), 267 consistent with a transition between $\mathrm{Pu}(\mathrm{III})$ and $\mathrm{Pu}(\mathrm{IV})$, even though a clear conclusion is 268 hampered by the relatively large uncertainty of measured pe data. This observation will be 269 supported by surface complexation modeling (see below).

271 Modeling results. As previously found for $\mathrm{Np}(\mathrm{V})$ interaction with illite and $\mathrm{Pu}$ sorption to 272 kaolinite and hematite, the redox speciation of actinides is influenced by the formation of surface 273 complexes. ${ }^{13,17,35}$ Equation 2 provides a simple approach to determine the stability field of Pu(IV) 274 and $\mathrm{Pu}(\mathrm{III})$ at a mineral surface: ${ }^{17}$

$$
\{P u(I V) / P u(I I I)\}_{\text {surf }}=\{P u(I V) / P u(I I I)\}_{a q}+\left(\log R_{d}(P u(I I I))-\log R_{d}(P u(I V))\right)
$$


$278\{\mathrm{Pu}(\mathrm{IV}) / \mathrm{Pu}(\mathrm{III})\}_{\text {aq }}$ can be calculated by the Nernst equation (see reference 17 for details) and the 279 redox borderline in aqueous solution (Figures 1 and $3 \mathrm{a}$ ) denotes an equimolar $\mathrm{Pu}(\mathrm{III}) / \mathrm{Pu}(\mathrm{IV})$ 280 ratio. $\{\mathrm{Pu}(\mathrm{IV}) / \mathrm{Pu}(\mathrm{III})\}_{\text {surf }}$ refers to the corresponding redox speciation at the illite surface. $\mathrm{Log}$ $281 \mathrm{R}_{\mathrm{d}}(\mathrm{Pu}(\mathrm{III}))$ and $\log \mathrm{R}_{\mathrm{d}}(\mathrm{Pu}(\mathrm{IV}))$ values in eq. 2 represent the respective individual uptake of the 282 two Pu redox states under the same physico-chemical conditions and are expressed as distribution 283 coefficients (denoted as $\mathrm{K}_{d}$ in reference 17). As $\mathrm{R}_{\mathrm{d}}$ values for $\mathrm{Pu}(\mathrm{III})$ and $\mathrm{Pu}(\mathrm{IV})$ are difficult to 284 determine separately, we took in a first approach existing models for $\mathrm{Eu}(\mathrm{III})^{19}$ and $\mathrm{Np}(\mathrm{IV})^{13}$ to 285 estimate sorption of $\mathrm{Pu}(\mathrm{III})$ and $\mathrm{Pu}(\mathrm{IV})$, respectively. The resulting $\mathrm{Pu}(\mathrm{IV}) / \mathrm{Pu}(\mathrm{III})$ borderline is 286 shown in Figure 3a as a dashed bold red line. $\mathrm{pH}$-edges for $\mathrm{Eu}(\mathrm{III})$ and $\mathrm{Np}$ (IV) sorption onto illite 287 in $0.1 \mathrm{M} \mathrm{NaCl}$ calculated with the $2 \mathrm{SPNE} \mathrm{SC} / \mathrm{CE}$ model are shown in Figure $3 \mathrm{~b}$. For $\mathrm{pH}<7$, $288 \mathrm{Eu}(\mathrm{III})$ sorption to illite is weaker than that of $\mathrm{Np}$ (IV). At this low $\mathrm{pH}$ outer-sphere sorption (ion 289 exchange) dominates for Eu(III). Due to the higher thermodynamic stability of actinide(IV) 290 surface complexes in this area, the predominance field of $\mathrm{Pu}(\mathrm{IV})$ is enlarged at the illite surface 291 and overlaps with the stability field of $\mathrm{Pu}(\mathrm{III})$ in the aqueous phase. For $\mathrm{pH}>7, \mathrm{Eu}(\mathrm{III})$ and $292 \mathrm{~Np}(\mathrm{IV})$ uptake are almost equal. As a consequence, the $\mathrm{Pu}(\mathrm{IV}) / \mathrm{Pu}(\mathrm{III})$ borderline at the illite 293 surface coincides with that in solution $\left(\{\mathrm{Pu}(\mathrm{IV}) / \mathrm{Pu}(\mathrm{III})\}_{\text {surf }} \approx\{\mathrm{Pu}(\mathrm{IV}) / \mathrm{Pu}(\mathrm{III})\}_{\text {aq }}\right)$. The pH-pe 294 values measured after 1 year in the Pu-illite suspensions are also plotted in Figure $3 \mathrm{a}$. According 295 to these estimations, $\mathrm{Pu}(\mathrm{IV})$ is expected to prevail (or, at least, to be present in significant 296 amounts) at the illite surface in all samples. For $\mathrm{pH}>6, \mathrm{Pu}(\mathrm{III})$ becomes negligible and $\mathrm{Pu}$ 297 speciation in solution and at the illite surface is controlled by $\mathrm{Pu}(\mathrm{IV})$. For $\mathrm{pH}<5$, the overall $\mathrm{Pu}$ 298 uptake by illite is predicted to lie between that of $\mathrm{Eu}(\mathrm{III})$ and $\mathrm{Np}(\mathrm{IV})$, which is indeed the case 299 according to experimental data (Figure 3b).

300 We performed $\mathrm{Eu}(\mathrm{III})$ uptake experiments in $0.1 \mathrm{M} \mathrm{NaCl}\left([\mathrm{Eu}]_{\mathrm{tot}}=3 \times 10^{-9} \mathrm{M}\right)$ for $3<\mathrm{pH}<9$ with 301 our illite batch in order to exclude the possible impact of different clay mineral batches with 
slightly variable surface properties (e.g. due to application of different purification procedures)

303 on sorption. As shown in Fig. S2, the 2 SPNE SC/CE model with the set of surface complexation 304 constants determined for $\mathrm{Eu}(\mathrm{III})^{19}$ predicts the experimental data fairly well without any 305 parameter adjustment. As discussed previously, ${ }^{13}$ the estimated surface complexation constants for $\mathrm{Np}(\mathrm{IV})$ are based on various assumptions and affected by relatively large uncertainties (i.e. an error of \pm 1.1 on $\log \mathrm{K}$ values for the $2 \mathrm{SPNE} \mathrm{SC} / \mathrm{CE}$ model) for various reasons and are restricted to $4<\mathrm{pH}<10$. According to our pe measurements, only $\mathrm{Pu}(\mathrm{IV})$ is expected in solution 309 for $\mathrm{pH}>6$ after 1 year, as confirmed by Pu redox state analysis. According to our calculations, no 310 redox state of $\mathrm{Pu}$ other than $\mathrm{Pu}(\mathrm{IV})$ should be present at the surface for $\mathrm{pH}>6$. We, therefore, 311 conclude that our data are representative of the sorption behavior of $\mathrm{Pu}(\mathrm{IV})$ and that they can be 312 used to derive more precise surface complexation constants for tetravalent $\mathrm{Pu}$ (Table S2). The 313 respective constants lie below those reported earlier for $\mathrm{Np}$ (IV) but still within the uncertainty 314 ranges (Figure S3). To describe $\mathrm{Pu}(\mathrm{IV}$ ) sorption at $\mathrm{pH}<4$ (Figure 3b) we included the $315 \equiv \mathrm{SOPuOH}^{2+}$ surface complex in order to be consistent with sorption data for other tetravalent 316 cations (Th(IV) $)^{21}$ and $\mathrm{Sn}(\mathrm{IV})^{20}$, see Figure S3) that do not exhibit a $\mathrm{R}_{\mathrm{d}}$ decrease at $\mathrm{pH}<4$ as is 317 the case for simulated $\mathrm{Np}(\mathrm{IV})$ data. Results are shown as the blue line in Figure $3 \mathrm{~b}$. Applying 318 those new surface complexation data in Table S2 does not result in major changes for the 319 resulting $\{\mathrm{Pu}(\mathrm{IV}) / \mathrm{Pu}(\mathrm{III})\}_{\text {surf }}$ borderline (Figure 3a, bold red line). Our above conclusions remain 320 valid.

321 Using the 2 SPNE SC/CE model with the surface complexation constants in Table S2 and taking 322 into account the range of measured redox conditions $(\mathrm{pH}+\mathrm{pe}=11.8 \pm 1.0$; Figure. $3 \mathrm{a})$ allows for 323 an excellent simulation of experimental $\mathrm{Pu}$ sorption data over the whole $\mathrm{pH}$-range investigated 324 (Figure 2a). Decreasing $\mathrm{R}_{\mathrm{d}}$ values at $\mathrm{pH}<5$ are nicely reproduced as a consequence of 325 progressing reduction of $\mathrm{Pu}(\mathrm{IV})$ to $\mathrm{Pu}(\mathrm{III})$ with decreasing $\mathrm{pH}$. Variations in $\log \mathrm{R}_{\mathrm{d}}$ for $\mathrm{pH}=4.3$ 
326 are assigned to the effect of pe rather than to a concentration effect (Fig. 2c). For $6<$ pe $<8.5$,

$327 \mathrm{Pu}(\mathrm{III})$ prevails in solution whereas Pu(IV) prevails at the illite surface. This explains why $\log \mathrm{R}_{\mathrm{d}}$

328 values lie between that of $\mathrm{Pu}(\mathrm{III})$ and $\mathrm{Pu}(\mathrm{IV})$, when they occur as single components.

330 Environmental implications. These results related to $\mathrm{Pu}(\mathrm{IV}) / \mathrm{Pu}(\mathrm{III})$ transition in presence 331 of illite, together with the outcome of earlier studies such as $\mathrm{Pu}(\mathrm{V}) / \mathrm{Pu}(\mathrm{IV})$ redox reactions in 332 aqueous kaolinite suspensions ${ }^{17}$ or the $\mathrm{Np}(\mathrm{V}) / \mathrm{Np}(\mathrm{IV})$ transition in presence of illite, ${ }^{13}$ 333 demonstrate the applicability of our approach to describe actinide redox reactions in presence of 334 mineral surfaces over a wide range of possible redox conditions where $\mathrm{Pu}(\mathrm{III}), \mathrm{Pu}(\mathrm{IV})$ and $\mathrm{Pu}(\mathrm{V})$ 335 may exist. A more accurate simulation of redox sensitive element behavior in near surface soil 336 systems and deep geological formations becomes possible by implementing measured pe values 337 of a given system into geochemical surface speciation calculations. Therefore, this study may 338 allow a more accurate estimation of Pu mobility in the geosphere. Because natural systems can be

339 much more complicated, containing e.g. carbonates and natural organic matter, further studies are 340 required to verify the applicability of the present approach to a wider range of geochemical 341 conditions. Our approach might also be tested for redox sensitive elements other than actinides 342 (e.g. cerium, selenium, arsenic, chromium, iron).

\section{ASSOCIATED CONTENT}

345 Materials and Methods: Extraction methods, Pu oxidation state analysis. Results and Discussion: 346 Thermodynamic calculations (Surface complexation, cation exchange, SIT parameters), 347 Experimental sorption data. This material is available free of charge via the Internet at $348 \quad$ http://pubs.acs.org. 
350 AUTHOR INFORMATION

351 Corresponding Author

$352 *$ nidhu.banik@kit.edu

\section{Present Addresses}

$355{ }^{\dagger}$ Ecole Nationale Supérieure de Chimie de Rennes, UMR CNRS 6226, 11 Allée de Beaulieu, F35635708 Rennes Cedex 7, France.

$357{ }^{\#}$ Groupe d'Etudes Atomiques (GEA), Ecole des Applications Militaires de l'Energie Atomique 358 (EAMEA). BCRM Cherbourg, CC19 50115 Cherbourg-Octeville Cedex, France

$360 \quad$ Notes

361 The authors declare no competing financial interest.

362

363 ACKNOWLEDGEMENTS

364 This work was financed by the Federal Ministry of Economic Affairs and Energy (Germany) 365 under contracts No. 02E10206 and 02E10961. The research leading to these results has received 366 funding from the European Union's European Atomic Energy Community's (Euratom) Seventh 367 Framework Program FP7/2007-2011 under grant agreement $n^{\circ} 249624$ (CATCLAY project). 


\section{REFERENCES}

371 (1) Altmaier, M.; Gaona, X.; Fanghanel, T. Recent advances in aqueous actinide chemistry and 372 thermodynamics. Chemical Reviews 2013, 113 (2), 901-943.

373 (2) Geckeis, H.; Lutzenkirchen, J.; Polly, R.; Rabung, T.; Schmidt, M. Mineral-Water interface reactions of actinides. Chemical Reviews 2013, 113 (2), 1016-1062.

(3) Begg, J. D.; Zavarin, M.; Zhao, P. H.; Tumey, S. J.; Powell, B.; Kersting, A. B. Pu(V) and $\mathrm{Pu}(\mathrm{IV})$ sorption to montmorillonite. Environmental Science \& Technology 2013, 47 (10), 51465153.

(4) Zavarin, M.; Powell, B. A.; Bourbin, M.; Zhao, P. H.; Kersting, A. B. Np(V) and Pu(V) ion exchange and surface-mediated reduction mechanisms on montmorillonite. Environmental

$380 \quad$ Science \& Technology 2012, 46 (5), 2692-2698.

381 (5) Tinnacher, R. M.; Begg, J. D.; Mason, H.; Ranville, J.; Powell, B. A.; Wong, J. C.; Kersting, 382 A. B.; Zavarin M. Effect of Fulvic Acid Surface Coatings on Plutonium Sorption and Desorption 383 Kinetics on Goethite. Environmental Science \& Technology 2015, 49 (5), 2776-2785.

384 (6) Hixon, A. E.; Powell, B. A. Observed changes in the mechanism and rates of $\mathrm{Pu}(\mathrm{V})$ reduction 385 on hematite as a function of total plutonium concentration. Environmental Science \& Technology 386 2014, $48(16), 9255-9262$.

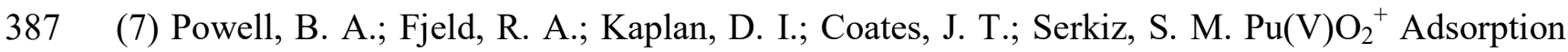
388 and Reduction by Synthetic Magnetite $\left(\mathrm{Fe}_{3} \mathrm{O}_{4}\right)$. Environmental Science \& Technology 2004, 38, $389 \quad 6016-6024$.

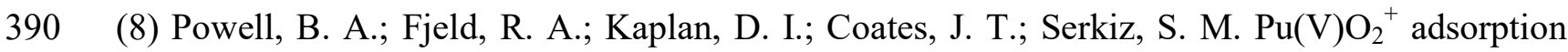
391 and reduction by synthetic hematite and goethite. Environmental Science \& Technology 2005, 39 392 (7), 2107-2114. 
393 (9) Romanchuk, A. Y.; Kalmykov, S. N.; Aliev, R. A. Plutonium sorption onto hematite colloids 394 at femto- and nanomolar concentrations. Radiochimica Acta 2011, 99, 137-144.

395 (10) Romanchuk, A. Y.; Kalmykov, S. N.; Egorov, A. V.; Zubavichus, Y. V.; Shiryaev, A. A.; 396 Batuk, O. N.; Conradson, S. D; Pankratov, D. A; Presnyakov, I. A. Formation of crystalline $397 \mathrm{PuO}_{2+\mathrm{x}}$ n. $\mathrm{H}_{2} \mathrm{O}$ nanoparticles upon sorption of $\mathrm{Pu}(\mathrm{V}, \mathrm{VI})$ onto hematite. Geochimica et 398 Cosmochimica Acta 2013, 121, 29-40.

399 (11) Hixon, A. E.; Arai, Y.; Powell, B. A. Examination of the effect of alpha radiolysis on 400 plutonium(V) sorption to quartz using multiple plutonium isotopes. Journal of Colloid and $401 \quad$ Interface Science 2013, 403, 105-112.

402 (12) Banik, N. L.; Buda, R. A.; Burger, S.; Kratz, J. V.; Trautmann, N. Sorption of tetravalent 403 plutonium and humic substances onto kaolinite. Radiochimica Acta 2007, 95, (10), 569-575.

404 (13) Marsac, R.; Banik, N. L.; Lutzenkirchen, J.; Marquardt, C. M.; Dardenne, K.; Schild, D.; 405 Rothe, J.; Diascorn, A.; Kupcik, T.; Schafer, T.; Geckeis, H. Neptunium redox speciation at the 406 illite surface. Geochimica et Cosmochimica Acta 2015, 152, 39-51.

407 (14) Guillaumont, R.; Fanghänel, Th.; Fuger, J.; Grenthe, I.; Neck, V.; Palmer, D. A.; Rand, M. 408 H. Update on the Chemical Thermodynamics of Uranium, Neptunium, Plutonium, Americium and 409 Technetium; Amsterdam, 2003.

410 (15) Kirsch, R.; Fellhauer, D.; Altmaier, M.; Neck, V.; Rossberg, A.; Fanghanel, T.; Charlet, L.; 411 Scheinost, A. C. Oxidation state and local structure of plutonium reacted with magnetite, 412 mackinawite, and chukanovite. Environmental Science \& Technology 2011, 45 (17), 7267-7274.

413 (16) Buda, R. A.; Banik, N. L.; Kratz, J. V.; Trautmann, N. Studies of the ternary systems humic 414 substances - kaolinite - Pu(III) and Pu(IV). Radiochimica Acta 2008, 96, 657-665. 
415 (17) Marsac, R.; Banik, N. L.; Lützenkirchen, J.; Buda, R. A.; Kratz, J. V.; Marquardt, C. M.

416 Modeling plutonium sorption to kaolinite: Accounting for redox equilibria and the stability of 417 surface species. Chemical Geology 2015, 400, 1-10.

418 (18) Choppin, G. R. Utility of oxidation state analogs in the study of plutonium behavior. 419 Radiochimica Acta 1999, 85, 89-95.

420 (19) Bradbury, M. H.; Baeyens, B.; Geckeis, H.; Rabung, T. Sorption of Eu(III)/Cm(III) on Ca421 montmorillonite and Na-illite. Part 2: Surface complexation modelling. Geochimica 422 Cosmochimica Acta 2005, 69, 5403-5412.

423 (20) Bradbury, M. H.; Baeyens, B. Sorption modelling on illite Part I: Titration measurements 424 and the sorption of Ni, Co, Eu and Sn. Geochimica et Cosmochimica Acta 2009, 73 (4), 9904251003.

426 (21) Bradbury, M. H.; Baeyens, B. Sorption modelling on illite. Part II: Actinide sorption and 427 linear free energy relationships. Geochimica et Cosmochimica Acta 2009, 73 (4), 1004-1013.

428 (22) Marquardt, C. M.; Seibert, A.; Artinger, R.; Denecke, M. A.; Kuczewski, B.; Schild, D.; 429 Fanghanel, T. The redox behaviour of plutonium in humic rich groundwater. Radiochimica Acta $430 \quad$ 2004, 92, (9-11), 617-623.

431 (23) Nitsche, H.; Roberts, K.; Xi, R. H.; Prussin, T.; Becraft, K.; Almahamid, I.; Silber, H. B.; 432 Carpenter, S. A.; Gatti, R. C.; Novak, C. F. Long-Term plutonium solubility and speciation 433 studies in a synthetic brine. Radiochimica Acta 1994, 66-7, 3-8.

434 (24) Neck, V.; Altmaier, M.; Seibert, A.; Yun, J. I.; Marquardt, C. M.; Fanghänel, Th. Solubility 435 and redox reactions of $\mathrm{Pu}(\mathrm{IV})$ hydrous oxide: Evidence for the formation of $\mathrm{PuO}_{2+\mathrm{x}(\mathrm{s}, \mathrm{hyd}) \text {. }}$ 436 Radiochimica Acta 2007, 95, 193-207.

437 (25) Kinniburgh, D. G., Cooper, D. M. PhreePlot: Creating graphical output with PHREEQC. 438 http://www.phreeplot.org. 2009. 
439 (26) Parkhurst, D. L.; Appelo, C. A. J. User's guide to PHREEQC (Version 2) - a computer 440 program for speciation, batch reaction, one-dimensional transport and inverse geochemical 441 calculation; Denver, Colorado, 1999; PP 312.

442 (27) Ciavatta, L. The specific interaction theory in evaluating ionic equilibria. Annali Di Chimica 443 1980, 70, (11-1), 551-567.

444 (28) Gorgeon, L. Contribution à la modélisation physico-chimique de la rétention de 445 radioéléments à vie longue par des matériaux argileux. Ph.D. thesis, Université Paris 6, 1994.

446 (29) Farr, J. D.; Neu, M. P.; Schulze, R. K.; Honeyman, B. D. Plutonium uptake by brucite and 447 hydroxylated periclase. Journal of Alloys and Compounds 2007, 444, 533-539.

448 (30) Bauer, A.; Berger, G. Kaolinite and smectite dissolution rate in high molar KOH solutions at $44935^{\circ}$ and $80^{\circ} \mathrm{C}$. Applied Geochemistry 1998, 13, 905-916.

450 (31) Rabung, T.; Pierret, M. C.; Bauer, A.; Geckeis, H.; Bradbury, M. H.; Baeyens, B. Sorption 451 of $\mathrm{Eu}(\mathrm{III}) / \mathrm{Cm}$ (III) on Ca-montmorillonite and Na-illite. Part 1: Batch sorption and time-resolved 452 laser fluorescence spectroscopy experiments. Geochimica Cosmochimica Acta 2005, 69, 53934535402.

454 (32) Finck, N.; Schlegel, M. L.; Bosbach, D. Sites of Lu(III) Sorbed to and Coprecipitated with 455 Hectorite. Environmental Science \& Technology 2009, 43 (23), 8807-8812.

456 (33) Bradbury, M. H.; Baeyens, B. Predictive sorption modelling of Ni(II), Co(II), Eu(IIII), 457 Th(IV) and U(VI) on MX-80 bentonite and Opalinus Clay: A "bottom-up" approach. Applied 458 Clay Science 2011, 52, 27-33.

459 (34) Marques Fernandes, M; Vér, N.; Bart Baeyens, B. Predicting the uptake of Cs, Co, Ni, Eu, 460 Th and $U$ on argillaceous rocks using sorption models for illite. Applied Geochemistry 2015, 59, $461 \quad 189-199$. 
462 (35) Kalmykov, S. N.; Vlasova, I. E; Romanchuk, A. Y.; Zakharova, E. V.; Volkova, A. G.;

463 Presnyakov, I. A. Partitioning and speciation of $\mathrm{Pu}$ in the sedimentary rocks aquifer from the 464 deep liquid nuclear waste disposal. Radiochimica Acta 2015, 103 (3), 175-185.

465 


\section{Figure Caption}

467 Figure 1. pH-pe values measured in illite suspensions under anaerobic conditions. Present work:

4681 week (gray diamonds) and 1 year equilibration time (black diamonds); previous investigations 469 of the Np-illite system: white circles. ${ }^{13}$ Large symbols indicate the samples where the supernatant 470 was analyzed by liquid extraction $\left([\mathrm{Pu}]_{\text {tot }}=10^{-8} \mathrm{M}\right)$. The predominance $\mathrm{pH}$-pe diagram for $\mathrm{Pu}$ in $471 \quad 0.1 \mathrm{M} \mathrm{NaCl}$ (solid lines) is also shown.

Figure 2. (a) $\mathrm{Pu}$ sorption to illite $\left(\mathrm{R}_{\mathrm{d}}\right.$ : distribution coefficient in $\left.\mathrm{L} \mathrm{kg}^{-1}\right)$ in $0.1 \mathrm{M} \mathrm{NaCl}$ as a 473 function of the $\mathrm{pH}\left(8 \times 10^{-11}<[\mathrm{Pu}]_{\text {tot }}<10^{-8} \mathrm{M}\right)$ after 1 week (white squares) and 1 year (black 474 diamonds) contact time. Results after 1 year are compared with overall $\log \mathrm{R}_{\mathrm{d}}$ calculated for $\mathrm{pH}+$ 475 pe $=11.8 \pm 1.0$ (bold line; lower and upper values: dashed and dashed-dotted lines, respectively; se text for more details). (b) log-log plot of $\mathrm{R}_{\mathrm{d}}$ versus the final aqueous $\mathrm{Pu}$ concentration $\left([\mathrm{Pu}]_{\mathrm{aq}}\right)$

477 for $\mathrm{pH}=4.3$ (black triangles) and $\mathrm{pH}>5$ (gray circles) after 1 year contact time. Average value 478 and standard deviation of $\log \mathrm{R}_{\mathrm{d}}(5.2 \pm 0.2)$ for $\mathrm{pH}>5$ are shown as gray solid and dashed lines, respectively. (c) Experimental and calculated $\log \mathrm{R}_{\mathrm{d}}$ values for $\mathrm{pH}=4.3$ versus pe.

480 Figure 3. (a) Predominance $\mathrm{pH}$-pe diagram for $\mathrm{Pu}$ in $0.1 \mathrm{M} \mathrm{NaCl}$ with $\mathrm{pH}$-pe values measured in 481 illite suspensions after 1 year equilibration time. The bold and dashed red lines show estimated 482 borderlines for $\mathrm{Pu}(\mathrm{IV}) / \mathrm{Pu}(\mathrm{III})$ redox transition at the illite surface (see text for more details). 483 Relevant redox conditions for this study $(\mathrm{pH}+\mathrm{pe}=11.8 \pm 1.0)$ are shown as straight (solid and 484 dashed) lines. (b) Data for Pu uptake onto illite $\left(\mathrm{R}_{\mathrm{d}}\right.$ in $\left.\mathrm{L} \mathrm{kg}^{-1}\right)$ as a function of $\mathrm{pH}$ compared with 485 model calculations for $\mathrm{Eu}(\mathrm{III})$ (green bold line), $\mathrm{Np}$ (IV) (dashed black line) and $\mathrm{Pu}(\mathrm{IV})$ (blue 486 bold line) sorption based on the 2 SPNE SC/CE model. 


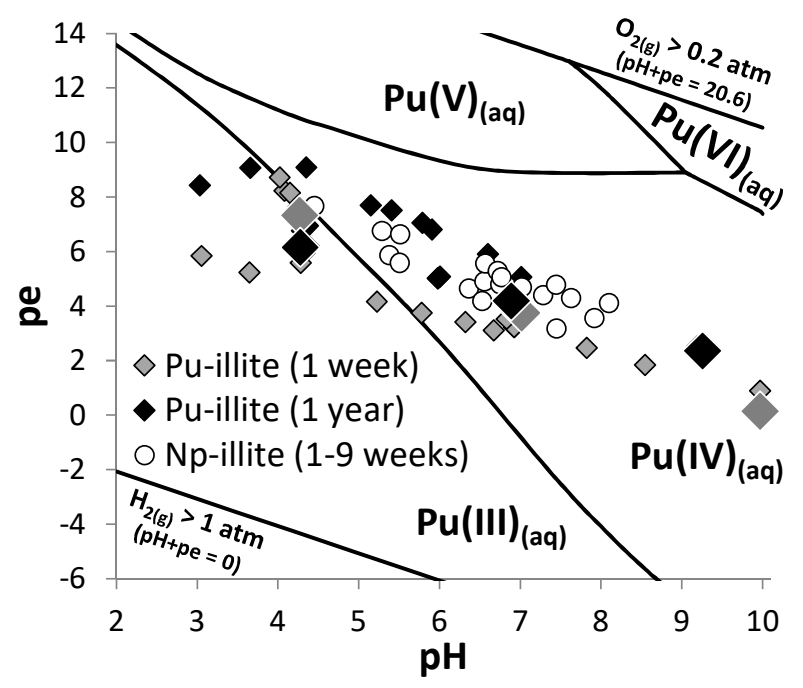



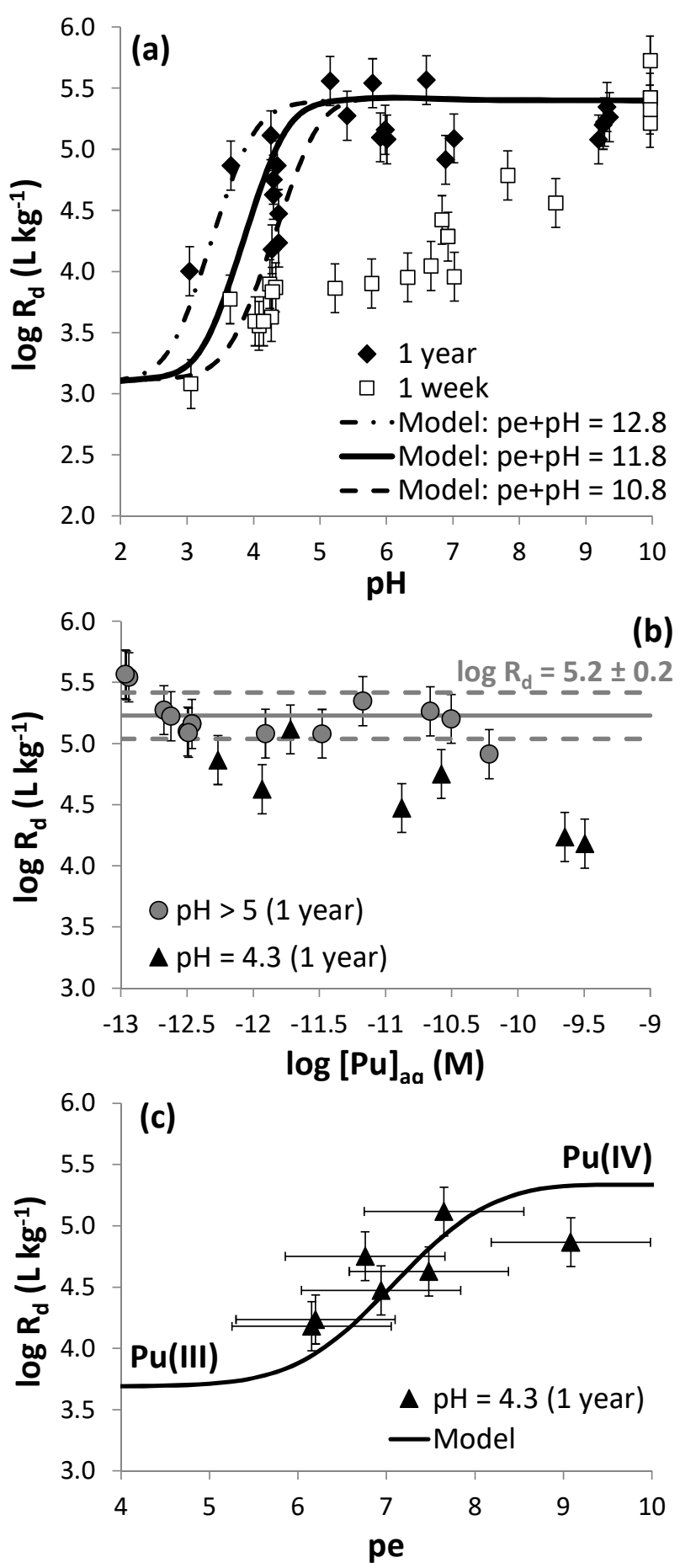

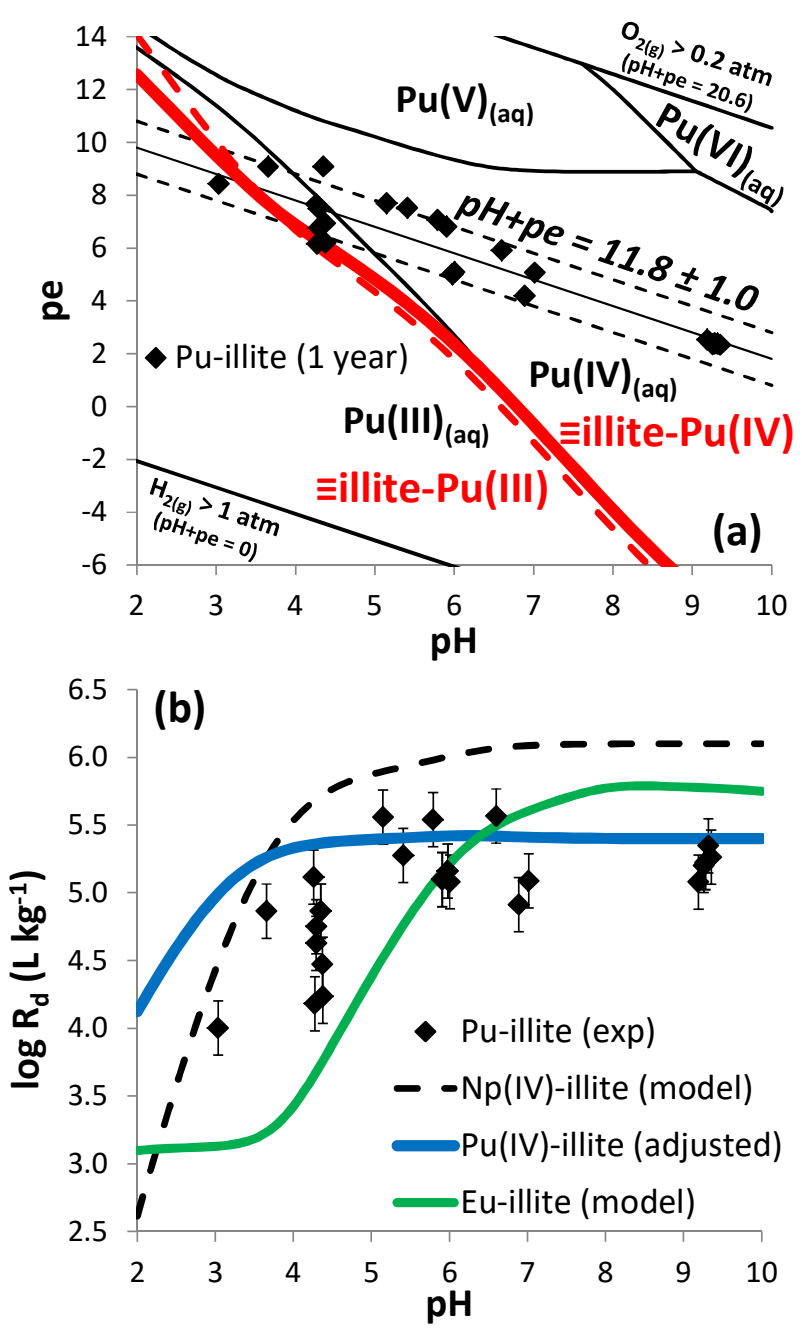

495 


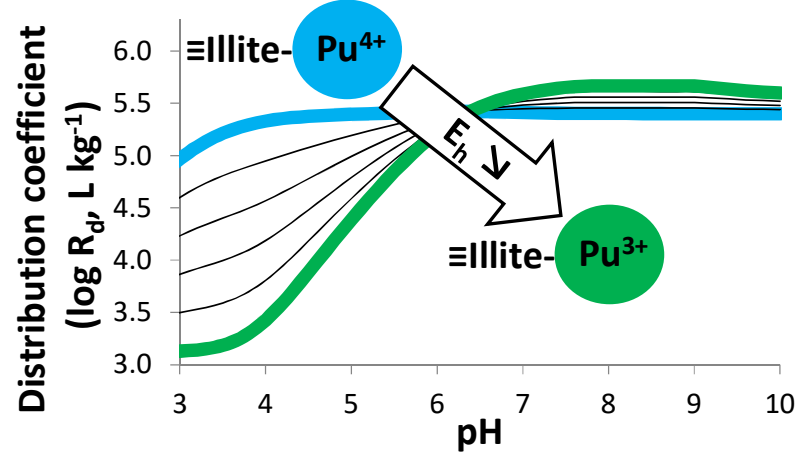

